Article (refereed) - postprint

Qarri, Flora; Lazo, Pranvera; Stafilov, Trajce; Frontasyeva, Marina; Harmens, Harry; Bekteshi, Lirim; Baceva, Katerina; Goryainova, Zoya. 2014. Multielements atmospheric deposition study in Albania. Environmental Science and Pollution Research, 21 (4). 2506-2518. 10.1007/s11356-013$\underline{2091-1}$

(c) Springer-Verlag Berlin Heidelberg 2013

This version available http://nora.nerc.ac.uk/503717/

NERC has developed NORA to enable users to access research outputs wholly or partially funded by NERC. Copyright and other rights for material on this site are retained by the rights owners. Users should read the terms and conditions of use of this material at http://nora.nerc.ac.uk/policies.html\#access

This document is the author's final manuscript version of the journal article, incorporating any revisions agreed during the peer review process. Some differences between this and the publisher's version remain. You are advised to consult the publisher's version if you wish to cite from this article.

The final publication is available at Springer via http://dx.doi.org/10.1007/s11356-013-2091-1

Contact CEH NORA team at noraceh@ceh.ac.uk

The NERC and CEH trademarks and logos ('the Trademarks') are registered trademarks of NERC in the UK and other countries, and may not be used without the prior written consent of the Trademark owner. 


\section{Multi-elements atmospheric deposition study in Albania}

\begin{abstract}
For the first time the moss biomonitoring technique and ICP-AES analytical technique were applied to study multi-elements atmospheric deposition in Albania. Moss samples (Hypnum cupressiforme) were collected during the summer of 2011 and September - October 2010 from 62 sites evenly distributed over the country. Sampling was performed in accordance with the LRTAP Convention - ICP Vegetation protocol and sampling strategy of the European Programme on Biomonitoring of Heavy Metal Atmospheric Deposition. ICP-AES analysis made it possible to determine concentrations of 19 elements including key toxic metals such as $\mathrm{Pb}, \mathrm{Cd}$, As, and $\mathrm{Cu}$. Cluster and Factor analysis with Varimax Rotation was applied to distinguish elements mainly of anthropogenic origin from those predominantly originating from natural sources. Geographical distribution maps of the elements over the sampled territory were constructed using GIS technology. The median values of the elements in moss samples of Albania were high for $\mathrm{Al}, \mathrm{Cr}, \mathrm{Ni}, \mathrm{Fe}$ and $\mathrm{V}$ and low for $\mathrm{Cd}$, Cu and $\mathrm{Zn}$ compared to the many other European countries, but generally were of a similar level as some of the neighbouring countries such as Bulgaria, Croatia, Kosovo, Macedonia and Romania. This study was conducted in the framework of ICP Vegetation in order to provide a reliable assessment of air quality throughout Albania and to produce information needed for better identification of contamination sources and improving the potential for assessing environmental and health risks in Albania, associated with toxic metals.
\end{abstract}

Keywords: moss biomonitoring; atmospheric deposition; trace elements; ICP-AES analysis; multivariate analysis, GIS technology

\section{Introduction}

Air quality can be monitored by measuring the concentration of pollutants in the air or directly on deposits, by building models that describe the transport of pollutants or by using biomonitors (Markert et al. 2003). Biomonitoring is a means to detect the deposition, accumulation and distribution of trace metals in ecosystems. Through the use of different types of vegetation, the levels of atmospheric trace metal deposition have been successfully monitored (Schilling et al. 2002). Ectohydric mosses can act as sensitive bioindicators as well as bioaccumulators of metal deposition in the environment (Vujičić et al. 2010). The ability of ectohydric mosses to retain potentially toxic elements has lead to their use as monitors of air pollution (Rühling and Tyler, 1984, 2004). The most important properties of ecotohydric mosses that make them suitable as biomonitors for monitoring air pollutants (Onianwa 2001; Zeichmeister et al. 2003) are related to the fact that they take up nutrients and trace elements directly from wet and dry deposition. Nutrient and element capture from the atmosphere is aided by the fact that ectohydric mosses have no vascular root system or waxy cuticle layer; hence, mineral adsorption occurs over their entire surface (Rühling and Tyler 1968). The high ion exchange capacity and high surface to volume ratio favour the accumulation of the high concentrations of heavy metals across the moss cell wall with time of exposure (Markert et al.1999; Fernandez et al. 2002).

The use of native terrestrial ectohydric mosses as biomonitors is now a well-recognized technique in studies of atmospheric contamination (Fernandez and Carballeira 2002; Harmens et al. 2010, 2011, 2013) and is applied as a practical mode in establishing and characterizing deposition sources.

The spatial distribution of 19 elements throughout the Albanian territory (62 sites) using the moss biomonitoring technique was explored in this research. For comparison the Albanian data were compared with neighboring countries (Harmens et.al 2013) and with Norwegian moss data from a pristine area (Steinnes et al. 2007). For better interpretation of the results, the contamination factors (CF) scales (Fernandez and Carballeira 2001) were used to interpret the results of CFs values obtained in this study and to distinguish the contamination level caused by each element. The scale is based on specific approach to terrestrial mosses, established by Fernandez et al. (2000) that allows categorization of determined sampling sites in terms of the CF values for each element while taking into account the method of dispersion of contaminants in the atmosphere. The contamination factors are calculated as the ratio of the median value of each element for Albanian mosses and the median value of each element for Norwegian mosses, which are considered as background level. The aim of this study was to 
investigate spatial trends of trace metals deposition in Albania by using mosses as biomonitors and to identify the problematic local sources of emissions.

\section{MATERIALS AND METHODS Sampling}

Sampling was performed in a relatively dry season in September - October 2010 and June-July 2011 to a total of 62 sampling stations. Sampling locations were not evenly distributed due to geographical problems. All moss samples were collected and identified under the supervision of J. Marka from the Department of Biology, Faculty of Natural Sciences, University of Tirana; Marka and Sabovljevic (2011) recently listed bryophyte records from Albania.

Sampling was performed according to the guidelines of the LRTAP Convention - ICP Vegetation protocol and sampling strategy of the European Programme on Biomonitoring of Heavy Metal Atmospheric Deposition (ICP Vegetation 2010). One of the recommended moss species, Hypnum cupressiforme, occurs widespread in Albania. The sampling locations were situated at least 300 meter away from main roads or buildings and $100 \mathrm{~m}$ from small roads and single houses. Most of the samples were collected in open areas. Five to ten sub-samples were collected within an area of $50 \mathrm{~m}$ x $50 \mathrm{~m}$ and mixed in one composites sample. Samples material (litter and dead leaves). Most of sampling sites in mountain areas are positioned in deep valleys by keeping the altitude lower than $1000 \mathrm{~m}$. Only 5 samples in Korca-Pogradec region (Albania South-East) are collected from the plateaus region with an elevation lower than $1300 \mathrm{~m}$ (Points marked with "X” in Fig. 1).

The green or greenish-brown parts representing 3-5 years of growth of the plant were used for further analysis without washing or other treatments. To prevent any contamination of the samples, sampling and sample handling was performed using disposable polyethylene gloves. The distribution of the sampling sites and their geographic coordinates are shown in Fig. 1.

Fig. 1 Map of Albania with moss sampling sites and their coordinates

\section{Sample Preparation}

Unwashed green and green-brown parts of the moss were removed in dry conditions and cleaned from the foreign materials adhered to the surface of the samples such as tree bark, lichens, soil dust and dead materials. The samples were dried to constant weight for 48 hours at $30-35^{\circ} \mathrm{C}$. To reduce particle size and satisfy the conditions for homogeneity of the sample, the samples were ground and homogenized prior to analysis, using a mortar and pestle.

\section{Chemical Analysis}

The content of 19 elements (Al, As, Ba, Ca, Cd, Cr, Cu, Fe, K, Li, Mg, Mn, Na, Ni, P, Pb, Sr, V and Zn) in the moss samples was determined by inductively coupled plasma - atomic emission spectrometric (ICP-AES) (Varian, 715ES) and electrothermal atomic absorption spectrometry (ETAAS) for the determination of As and Cd (Varian, SpectrAA 640Z), performed at the Institute of Chemistry, Faculty of Science, Sts. Cyril and Methodius University, Skopje, Macedonia. Ultrasonic nebulizer CETAC (ICP/U-5000AT+) was used with ICPAES for better sensitivity and signal stability. The solution used for preparing standard solution had a concentration of $1000 \mathrm{mg} \mathrm{L}^{-1}$ (Merck, ICP Multielement standard solution IV). P and V were added to ICP multi-element standard solution IV from the Merck Sertpur standard solutions $\left(1000 \mathrm{mg} \mathrm{L}^{-1}\right)$. The concentrations of the elements in calibration solutions were 0.01, 0.03, 0.05, 0.1, 1.0 and 5.0 $\mathrm{mg} / \mathrm{L}$ for trace elements $(\mathrm{Ba}, \mathrm{Cr}$, $\mathrm{Cu}, \mathrm{Li}, \mathrm{Ni}, \mathrm{Pb}, \mathrm{Sr}, \mathrm{Zn}$ and V) and additionally included 10, 50, $100 \mathrm{mg} / \mathrm{L}$ for the other elements (Al Ca, Fe, K, $\mathrm{Mg}$. Mn, Na and P). The standard solutions for As and Cd in the ETAAS analysis were also prepared from the Merck Sertpur standard solution $\left(1000 \mathrm{mg} \mathrm{L}^{-1}\right)$. The concentrations of Cd and As in calibration solutions were 0.5, 1.0, 2.0 and $5 \mu \mathrm{g} \mathrm{L}^{-1}$ and 5.0, 10, 20 and $50 \mu \mathrm{g} \mathrm{L}^{-1}$ respectively. The optimal instrumental conditions for the determination of As and Cd were given by Balabanova et al. (2010). The eventual mutual spectral interferences of spectral lines were checked and appropriate lines were used.

Moss samples were digested using a microwave digestion system (Mars, CEM, USA) according to the method presented by Barandovski et al. (2008) and Balabanova et al. (2010).

The detection limits calculated as 3 SD of the lowest instrumental measurements of the blanks are: $0.002 \mathrm{mg} \mathrm{kg}^{-1}$ for $\mathrm{Mn}$ and $\mathrm{Zn}, 0.005 \mathrm{mg} \mathrm{kg}^{-1}$ for $\mathrm{Cd}$ and Fe, $0.01 \mathrm{~kg}^{-1}$ for $\mathrm{Al}$, As and $\mathrm{Cu}, 0.025 \mathrm{mg} \mathrm{kg}^{-1}$ for Ca, Ba, Mg and Sr, $0.05 \mathrm{mg} \mathrm{kg}^{-1}$ for $\mathrm{Cr}$, Li and V, $0.25 \mathrm{mg} \mathrm{kg}^{-1}$ for $\mathrm{Ni}$ and $\mathrm{Pb}, 0.5 \mathrm{mg} \mathrm{kg}^{-1}$ for P, $2.5 \mathrm{mg} \mathrm{kg}^{-1}$ for Na, $5 \mathrm{mg} \mathrm{kg}^{-1}$ for K. Appropriate limits of quantification were calculated as $10 \mathrm{SD}$ of the lowest instrumental measurements of the blanks: $0.007 \mathrm{mg} \mathrm{kg}^{-1}$ for Mn and Zn, $0.02 \mathrm{mg} \mathrm{kg}^{-1}$ for Cd and Fe, $0.035 \mathrm{~kg}^{-1}$ for Al, As and Cu, $0.085 \mathrm{mg} \mathrm{kg}^{-1}$ for Ca, Ba, Mg and Sr, $0.2 \mathrm{mg} \mathrm{kg}^{-1}$ for Cr, Li and V, $0.85 \mathrm{mg} \mathrm{kg}^{-1}$ for Ni and Pb, $2 \mathrm{mg} \mathrm{kg}^{-1}$ for P and Pb, $8.5 \mathrm{mg}$ $\mathrm{kg}^{-1}$ for $\mathrm{Na}, 17 \mathrm{mg} \mathrm{kg}^{-1}$ for $\mathrm{K}$. Three replicates per moss sample were digested and three replicate measurements per digest were performed. 


\section{Quality Control}

The quality control of ICP-AES results was ensured by multiple analyses of the examined samples and moss reference materials M2 and M3 (Steinnes et al. 1997; Harmens et al. 2010). The measured concentrations were generally in good agreement with the recommended values (Table 1). Although recoveries were sometimes low (e.g. Ca in M2) or high (e.g. Cu in M3) in one of the reference material, this was not the case for the other reference material (e.g. Ca in M3 or $\mathrm{Cu}$ in M2). In addition, blanks were run parallel to the decomposition and the analysis of the samples.

Table 1. Recommended (Steinnes et al., 1997; Harmens et al., 2010) and obtained values for element concentration in reference moss samples M2 and M3.

\section{Statistical analysis}

Elemental concentration data were analyzed using Factor analysis (FA) in order to identify the main source categories of moss samples regarding site contamination and elements distribution. Data were processed by cluster and FA analysis with Varimax Rotation by using the MINTAB 15 software package.

The term cluster analysis encompasses a number of different methods for grouping objects with a certain similarity, into respective categories, by assuming that the degree of association between two objects is maximal if they belong to the same group and minimal otherwise. Cluster analysis simply discovers structures in data without explaining interpretation why they exist.

Factor analysis is a powerful tool for reducing a number of observed variables into a smaller number of artificial variables that account for most of the variance in the data set. FA is a variable reduction procedure. As the result of this redundancy, it should be possible to reduce the observed variables into a smaller number of principal components (artificial variables) that will account for most of the variance in the observed variables. Cluster and factor analyses, as important tools in multivariate statistical analysis, were used to identify and characterize the contamination sources and the most contaminated areas. The concentrations matrix of 19 elements in mosses from 62 sampling sites was used for a factor analysis by means of principal components. Cluster analysis (CA) is used to detect the groups of samples with similar patterns of element concentrations. The numbers of the groups and most important factors were determined. Factor analysis (FA) is a powerful technique often used in ecology to reduce the amount of data and stabilize subsequent statistical analyses (Vaughan and Ormerod 2005). FA plot of loadings were used to shows correlations between the original variables and the first two factors (Legendre 1998).

\section{Results and discussion}

The results of the descriptive statistics analysis of the elemental concentrations determined in the Albanian moss samples (min, max, mean and median, see Table 2) were compared with those of other Balkan countries and Norway (Table 3). The data from 2010 of a selected Norwegian moss study used as pristine area are shown in Table 3. The present median values of the elements associated with air pollution (V, Cr, Ni, Cu, As, Cd, $\mathrm{Pb}$ ) are generally comparable with those observed in Bulgaria, Croatia, Kosovo, Macedonia and Romania (Harmens et al. 2010 2013; Marinova et al. 2010; Thöni et al. 2011; Spiric et al. 2012; Barandovski et al. 2008, 2012; Stafilov et al. 2003; Balabanova et al. 2010, 2012; Bačeva et al. 2011, 2012), but substantially higher than the corresponding values from Norway (Steinnes 2011) or other European countries (Harmens et al. 2010, 2013). In principle we could use the Norwegian data for 2010 to establish the CF factor, however, this cannot be done because the data of 2010 belong to whole Norway, nor to a pristine area and not all the elements that we have determined are reported in the report for the 2010 moss survey (Harmens et al. 2013). Therefore, the Norwegian data of 2005 and 2010 are very close to each one, means the results do not appear high temporal variation (Harmens et al. 2013, Steinnes 2011).

$\mathrm{Al}, \mathrm{Cr}, \mathrm{Fe}, \mathrm{Ni}$ and $\mathrm{V}$ values are high in Albania, all related to wind-blown soil dust which represent historical deposition or originate from mineral soil layer, and in addition to industrial activity. $\mathrm{Cu}$, $\mathrm{Cd}$ and $\mathrm{Zn}$ concentrations were generally low in mosses sampled in Albania compared to many other European countries (Harmens et al. 2013). The order of the elements according to their abundance is: $\mathrm{Cd}<\mathrm{As}<\mathrm{Li}<\mathrm{Pb}<\mathrm{V}<\mathrm{Cu}<\mathrm{Ni}<\mathrm{Cr}<\mathrm{Zn}<\mathrm{Ba}<\mathrm{Sr}<\mathrm{Mn}<\mathrm{Na}<\mathrm{P}<\mathrm{Mg}<\mathrm{Fe}<\mathrm{Al}<\mathrm{K}<\mathrm{Ca}$.

Table 2 Descriptive statistics of mosses elements in Albania $(\mathrm{N}=62)(\mathrm{mg} / \mathrm{kg}, \mathrm{DW})$

Table 3 The comparison of median values from Albania and a a pristine region of Northern Norway (Steinnes 2007)

High variation exists in the concentrations of most elements in the moss samples. Coefficients of variation (CV) for most elements are moderate (25-75\%; Table 2). CV value is the highest for Ni (170\%) followed by As (118\%), Pb (98\%), Cd (97\%), Cr (85\%) and Zn (82\%). Only Ca has relatively weak variability, with CVs below 
25\%. Coefficients of skewness are greater than 2 for most elements, and only Ba, Ca and Mg have a coefficient lower than 2, indicating that the frequency distribution of most moss elements in the study area are strongly positively skewed. All the coefficients of kurtosis of moss elements exceed 0 , suggesting that most values are still concentrated around the central tendencies. The great variation, positively skewed distribution, and high kurtosis suggest that the trace element concentrations were affected by complicated factors (Wang et al. 2010). For better interpretation of the results, the contamination factors (CF) scales were calculated (Table 4).

Table 4 The data of the contamination factors (CF) and Contamination Classification (Fernandez et al. 2000) for metal concentrations in mosses in Albania.

By examining the CFs data of each element as shown in Table 4, a few observations can be made. The CFs results indicate that the elements $\mathrm{Mn}, \mathrm{Zn}, \mathrm{Ba}, \mathrm{Cd}, \mathrm{Cu}, \mathrm{Mg}$ and $\mathrm{Sr}$ are associated with the first two categories of scale, C1 and C2, i.e. uncontaminated areas (a CF of 2 can easily obtained from natural variation). As and Ca are associated with the contamination of the third category of scale, C3, described as slightly polluted areas. As and Ca originate mainly from sulfide minerals (Lazo et al. 2007); and calcium carbonates formation in some areas of Albania. From all of the 19 elements, there are a few metals associated with the moderately or severely polluted scale of classification, such as Fe, Ni, V $(\mathrm{CF}=4)$ and $\mathrm{Al}, \mathrm{Cr}(\mathrm{CF}=5)$. The distribution maps of $\mathrm{Al}, \mathrm{As}, \mathrm{Cr}, \mathrm{Fe}, \mathrm{Ni}$ and V (C3, C4 and C5 category of scale) are presented in Fig. 2.

Fig. 2 The map of elements distribution (Al, Cr, Fe, V and As; C5, C4 and C3 contamination scale, and Zn; C1 contamination scale)

The maps suggest a high level on wind-blow dust in the south and high level (for most metals) of industrial activity focused in the mid-east of Albania. The main contribution of $\mathrm{Cr}$, Fe, $\mathrm{Ni}$ and $\mathrm{V}$ elements is coming from the Elbasani ferrochromium metallurgical plant (Lazo et al., 2013) and mine industry in Albania.

\section{Correlation of the Data}

To distinguish between lithogenic and anthropogenic origin of the elements in moss samples, correlation analysis was carried out. The results of correlation analysis are shown in Table 5.

Table 5 Pearson Correlation Coefficient between element concentrations in mosses in Albania.

$$
\text { Cell Contents: P-Value: }{ }^{1} \mathrm{P}<0.001,{ }^{2} \mathrm{P}<0.005,{ }^{3} \mathrm{P}<0.01
$$

In table 6, linear regression is displayed for the significantly correlated elements $\left(\mathrm{R}^{2}>0.5, \mathrm{P}<0.005\right)$. The Hypotheses of Significance Test of Linear Regression was set and the t-test $(\mathrm{P}=0.95, \mathrm{~N}-2$ degree of freedom) was calculated by setting the following conditions:

1. The Null Hypothesis, H0: slope $=0$, meaning that the linear relationship between two elements $(\mathrm{x}$ and $\mathrm{y})$ is not significant vs. $(\alpha=0.05)$, and:

2. H1: slope $\neq 0$ ( $\alpha=0.05)$, meaning that the linear relationship between two elements ( $\mathrm{x}$ and $\mathrm{y})$ is significant.

Table 6 Statistical parameters of linear regressions between significantly correlated elements in mosses in Albania (tcrit( $0.05, \mathrm{~N}-2=60=2$ ).

\section{Multivariate analysis}

Through the results of Factor analysis, the extracted principal components were interpreted as source categories contributing to elements concentrations at the sampling sites. The identification of source categories was undertaken by examination of the profiles of the principal components, i.e, loadings of the elements and other variables on the Varimax Rotation (orthogonal). The main criteria in selecting the optimal models of source identification of major sources with physically reasonable principal components, is those Eigen values or variances larger than 1 after Varimax Rotation.

The moss samples No. 1 to 32 were collected during the first sampling campaign (September - October 2010) and the rest of samples (No. 33 to 62) were collected during the summer of 2011 (July and August 2011). Aiming to distinguish the influence of weather condition on elements concentration on the samples collected during different periods, the cluster analysis of the observations was done.

\section{Cluster Analysis of Observations (Station 1 to 62)}

Euclidean Distance, Median Linkage (Similarity Level: 70\%)

Final Partition: Number of clusters: 7 
Distances Between Cluster Centroids

cluster1

Cluster 2

cluster 3

Cluster 4

Cluster 5

Cluster 6

Cluster 7
Cluster1 Cluster2 Cluster 3

๑. $0 \odot$

3868.30

3444.51

7520.90

6839.67

4623.04

4376.43
3444.5

6808.8

๑. 0

10256.8

8567.5

5761.0

3953.7
3868.30

$\odot . \odot \odot$

6808.79

5486.77

6643.34

4299.78

5352.11

$\begin{array}{rrrr}\text { Number of } & \begin{array}{r}\text { Within } \\ \text { cluster sum } \\ \text { of squares }\end{array} & \begin{array}{r}\text { Average } \\ \text { distance } \\ \text { from }\end{array} & \begin{array}{r}\text { Maximum } \\ \text { distance } \\ \text { centroid }\end{array} \\ \begin{array}{r}\text { fromtroid } \\ \text { observations }\end{array} \\ 1 & 0 & 0.0 \odot & 0.0 \odot \\ 53 & 334305201 & 2367.84 & 4760.78 \\ 1 & 0 & 0.0 \odot & 0.0 \odot \\ 1 & 0 & 0.0 \odot & 0.0 \odot \\ 1 & 0 & 0.0 \odot & 0.0 \odot \\ 4 & 10342381 & 1570.34 & 2131.18 \\ 1 & 0 & 0.0 \odot & 0.0 \odot\end{array}$

Cluster 4
7520.9
5486.8
10256.8
0.0
4012.4
8665.9
9576.4

$\begin{array}{rr}\text { Cluster6 } & \text { Cluster } 7 \\ 4623.04 & 4376.43 \\ 4299.78 & 5352.11 \\ 5761.01 & 3953.67 \\ 8665.88 & 9576.36 \\ 8197.66 & 8571.25 \\ 0.00 & 3531.42 \\ 3531.42 & 0.0 \odot\end{array}$

Cluster 1: St.1 (Saranda), situated in the coastal area of Ion Sea; Cluster 2: The rest of 53 stations, distributed across the country; Cluster 3: St.35 (Mjekes), close to Elbasani Metallurgical plant, with a high content of Fe, $\mathrm{Cr}, \mathrm{Ca}, \mathrm{Pb}, \mathrm{Cu}$ and $\mathrm{Mn}$; Cluster 4: St.11 (Tepelena) is an ex-coal mining industry area. It has a high content of As,

V, Mn and Ca; Cluster 5: St.27, positioned in the North-East part of Tirana area, close to Dajti mountain; Cluster 6: St.34, 61, 51 and 38 (Balza, Terihat, Kruja and Lini). Cement industry is the main activity of the Balza and Kruja area, while Terihat is a calcium carbonate area. The classification of Lini station in the same group is not clear; Cluster 7: St.32 (Golem), situated in coastal area at the Adriatic Sea.

This classification, which put together the 53 samples collected during two different sampling campaigns (September - October 2010 and the summer of 2011, July and August 2011), does not show any influence caused by the weather conditions on elements concentration in moss samples.

To check the manner of elements distribution, the cluster analysis of variables (Correlation Coefficient Distance, Complete Linkage and Similarity Level 70\%) was conducted. The dendrogram of the correlation coefficients distance of deposited elements in mosses of Albania obtained from cluster analysis is presented in Fig. 3.

Fig. 3 Dendrogram of correlation coefficients for distance of clusters (Similarity level $=80 \%$ ) of deposited elements to mosses in Albania. Final Partition: Cluster 1: Cd; Cluster 2: As; Cluster 3: Cr, Li, V, $\mathrm{Al}$ and Fe; Cluster 4: $\mathrm{Cu}, \mathrm{Pb}$ and $\mathrm{Zn}$; Cluster 5: Ni and Mg; Cluster 6: Ba and Sr; Cluster 7: Na: Cluster 8: Mn; Cluster 9: P and K; Cluster 10: Ca

The dendrogram of correlation coefficients for distance of clusters (Fig. 3) shows that the deposited elements can be divided into 10 groups (similarity level 70\%):

Cluster (1) and (4) with 69\% of similarity level between them, contain the elements $\mathrm{Cu}, \mathrm{Pb}$ and $\mathrm{Zn}$. These elements are typical elements which are consequences of air transport and they are not influenced by lithological background. Road transport may have a considerable effect on the high content of $\mathrm{Pb}$ in mosses, while $\mathrm{Pb}$ acts as the marker element for motor vehicle emissions (Huang et al. 1994). $\mathrm{Zn}$ and $\mathrm{Cu}$ are mostly associated with city dust, traffic exhaust, soil and re-suspended road dust. $\mathrm{Zn}$ is present near the most heavy traffic areas in the central part of Albania and in the north of the central part of the country with high mineralization of sulfides (Lazo et al. 2007).

Cluster (2) and (10) with high similarity level between them, contain the elements As and Ca. Arsenic occurs naturally in soil and minerals and may enter the air as wind-blown dust particles (WBK \& Associates Inc. 2004). Cluster (3) and (6) with high similarity level between them, associated with the elements $\mathrm{Al}, \mathrm{Li}, \mathrm{V}, \mathrm{Cr}$ and $\mathrm{Fe}$ and $\mathrm{Ba}$ and $\mathrm{Sr}$. These associations may be attributed to their geogenic origin (Tume et al. 2010). The association $\mathrm{Cr}$ and Fe is also related to air pollution (Lazo et al. 2013). Their highest concentration (Fig. 2) is present near the ferrochromium metallurgy in Elbasani town and chromites deposition areas of Albania. Cluster (5): The presence of Mg and Ni in the same Cluster explains their mixed lithogenic (Rudnick 2003) and anthropogenic origin (Huang et al. 1994). The association of $\mathrm{Ni}$ and $\mathrm{Mg}$ is also related to air pollution. Cluster (7) contains only Na. Higher Na values in coastal areas are probably due to cation exchange on the moss surface with sea salt ions (Gjengedal and Steinnes 1990, Steinnes 1995) in coastal parts of the country. Cluster (8) contains only the element Mn, which may originate from both natural and anthropogenic sources. Natural emission sources of manganese to the atmosphere are the result of erosion of soils and dusts. 
Anthropogenic activities that lead to the release of manganese and manganese compounds to air include industrial activities (such as alloy production and steel foundries) and combustion of fossil fuels in power plants, coke ovens and automobiles (WBK \& Associates Inc. 2004).

Cluster (9) contains the elements $\mathrm{K}$ and $\mathrm{P}$, which are probably related to the high accumulation as well as poor retention of these luxury nutrients in mosses (Brown et al. 1990).

For a better interpretation of factors influencing element distribution in mosses, Factor Analysis with Varimax Rotation for Al, As, Ba, Ca, Cd, Cr, Cu, Fe, K, Li, Mg, Mn, Na, Ni, P, Pb, Sr, V and Zn was used (Table 7).

Table 7 Factor Loadings (Varimax Rotation) of moss elements in the studied area

Factor 1 is the strongest factor representing $24.4 \%$ of the total variance. It is influenced by high values of $\mathrm{Al}, \mathrm{Li}$, $\mathrm{Ba}, \mathrm{Sr}, \mathrm{V}, \mathrm{Fe}$ and As. This group of elements are probably naturally distributed as typically soil elements (Rudnick 2003). Most of these elements are typical of crustal material, and most probably this component may reflect the contamination of moss samples by soil particles. The presence of $\mathrm{Al}$ in this group is confirmation of this assumption, since $\mathrm{Al}$ compounds are insoluble and most of the $\mathrm{Al}$ found in biological systems comes from dust contamination.

Factor 2 is the second strongest factor, with $15.0 \%$ of the total variance. It is mainly influenced by high loadings of $\mathrm{Ni}, \mathrm{Mg}, \mathrm{Cr}$, and Fe. These elements are typical for chromites ores and may be associated with mining and ferrochromium metallurgy industries. The main contribution of these elements is coming from the Elbasani ferrochromium metallurgical plant (Lazo et al. 2013) and the chromium mine industry in Albania.

Factor 3 represents $13.8 \%$ of the total variance. This factor is negatively loaded with $\mathrm{Cu}, \mathrm{Pb}$ and $\mathrm{Zn}$, distinguished by typically anthropogenic source related mainly to traffic emissions. The negative loading values may indicate a reverse tendency of desorption or a decreasing concentration of these elements when the total metal concentrations increases, maybe indicating a great influence of weather conditions, wind speed (Wehner 2002) and the amount of precipitation being the main factors (Melaku et al. 2008).

Factor 4 represents $12.9 \%$ of the total variance. This factor is principally associated with negative loads of $\mathrm{P}, \mathrm{K}$ and Na. This could be associated with wet conditions, which may be specifically relevant for mobile elements such as sodium and potassium (IAEA-TECDOC-1338 2003).

Factor 5 represents only $8.4 \%$ of the total variance and is identified as the weakest factor. This factor is principally associated with high positive loads of $\mathrm{Mn}$ and moderate loads of $\mathrm{Cu}, \mathrm{Cd}$, As and $\mathrm{Al}$. Manganese does not occur as the free metal and is found in more than 100 minerals including various sulphides, oxides, carbonates, silicates, phosphates, and borates (Howe et al. 2004). Albania is rich in sulphides, carbonates, silicates and phosphates minerals, so geogenic origin of $\mathrm{Mn}$ in dust fine particles may be the main factor determining $\mathrm{Mn}$ in air.

\section{CONCLUSION}

This study confirms that moss biomonitoring is a valuable tool for the evaluation of atmospheric input of metals in the environment. The method is suitable for detecting spatial trends in heavy metal deposition. The differences in metals concentration in mosses between different parts of the country and the location of emission sources were expressed clearly, which reflect local variation in heavy metal deposition. Only a few metals that belong to the group of elements which caused moderate or severe contamination, such as $\mathrm{Fe}, \mathrm{Ni}, \mathrm{V}(\mathrm{CF}=4)$ and $\mathrm{Al}, \mathrm{Cr}(\mathrm{CF}=5)$. In comparison with similar studies made in neighbouring countries (Bulgaria, Croatia, Kosovo, Macedonia and Romania) the results obtained for Albania show a similar picture. The high contents of Al, Cr and Fe in mosses from Balkan countries indicated their geogenic source of origin. Cluster analysis in combination with Factor analysis proved to be a useful tool for the classification and identification of sources of air pollution, although the variability of the source apportionment estimates for some sources was rather large. In all, the results obtained were convincing enough to be used in atmospheric deposition studies investigating the trace elements in air pollution from different sources. The results obtained from the comparison of two source apportionment statistical methods were similar, especially regarding the level of similarity that we choose.

\section{Aknowledge:}

The authors would like to thank MSc. Jani Marka, Department of Biology, Faculty of Natural Sciences, University of Tirana, for supervising the sampling procedure and moss species identification. We would like to thank the Ph.D. students Ilva Gjika and Majlinda Terpo involved in sampling respectively at Tirana area and Saranda, Gjirokastra, Tepelena and Permet area. Harry Harmens would like to thank the UK Department for Environment, Food and Rural Affairs (Defra) for the continued financial support of the ICP Vegetation (Contract AQ0816). The United Nations Economic Commission for Europe (UNECE) and the UK Natural Environment Research Council (NERC) are also thanked for contributions to the funding of the ICP Vegetation Programme Coordination Centre. 


\section{REFERENCES}

Bačeva K, Stafilov T, Šajn R, Tănăselia C, Ilić PS (2011) Distribution of chemical elements in attic dust in the vicinity of ferronickel smelter plant, Fresenius Environmental Bulletin, Vol. 20(9), p. 2306-2314.

Bačeva K, Stafilov T, Šajn,R, Tănăselia C (2012) Moss biomonitoring of air pollution with heavy metals in the vicinity of a ferronickel smelter plant, Journal of Environmental Science and Health, Part A: Toxic/Hazardous Substances and Environmental Engineering, Vol. 47(4), p. 645-656.

Balabanova B, Stafilov T, Bačeva K, Šajn R (2010) Biomonitorıng of atmospherıc pollution with heavy metals in the copper mine vicınıty located near Radoviš, Republıc of Macedonia, Journal of Environmental Science and Health, Part A, Toxic/Hazardous Substance \& Environmental Engineering, Vol. 45, p. 1504-1518.

Balabanova B, Stafilov T, Šajn R, Bačeva K (2012) Characterisation of heavy metals in lichen species Hypogymnia Physodes and Evernia Prunastri due to biomonitoring of air pollution in the vicinity of copper mine, International Journal of Environmental Research, Vol. 6(3), p. 779-792

Barandovski L, Cekova M, Frontasyeva MV, Pavlov SS, Stafilov T, Steinnes E, Urumov V (2008) Atmospheric dep osition of trace element pollutants in Macedonia studied by the moss biomonitoring technique. Environmental Monitoring and Assessment, Vol. 138, p. 107-118.

Barandovski L, Frontasyeva MV, Stafilov T, Sajn R, Pavlov SS, Enimiteva V (2012) Trends of atmospheric deposition of trace elements in Macedonia studied by the moss biomonitoring technique. Journal of Environmental Science and Health, Part A; Taylor \& Francis, Vol. 47, p. 2000-2015. http://dx.doi.org/10.1080/10934529.2012.695267.

Brown D H, Bates J W (1990) Bryophytes and nutrient cycling, Botanical Journal of the Linnean Society, 04 129-147 Castello, M, A Comparison Between Two Moss Species Used as Transplants for Airborne Trace Element Biomonitoring in NE Italy 2007, Environmental Monitoring and Assessment 133(1-3):267-276

Fernandez J. A, Carballeira A (2002) Biomonitoring metal deposition in Galicia (NW Spain) with mosses: factors affecting bioconcentration.. Chemosphere. 46, 535-542

Fernandez JA, Ederra A, Nunez E, Martinez-Abaigar, J, Infante M, Heras P, Elias MJ, Mazimpaka V, Carballeira A (2002) Biomonitoring of metal deposition in northern Spain by moss analysis. Science of the Total Environment , 300 115-127.

Fernandez JA, Rey A, Carballeira A (2000) An extended study of heavy metal deposition in Galicia (NW Spain) based on moss analysis. Science of the Total Environment 254: 31-44. DOI: 10.1016/S0048-9697(00)00431-9

Fernandez JA, Carballeira A (2001) Evaluation of contamination, by different elements, in terrestrial mosses. Archives of Environmental Contamination and Toxicology, 40: 461-468. DOI: 10.1007/s002440010198

Gjengedal E, Steinnes E (1990) Uptake of metal ions in moss from artificial precipitation. Environmental Monitoring and Assessment 14, 77-87.

Harmens H, Foan L, Simon V, Mills G (2013) Terrestrial mosses as biomonitors of atmospheric POPs pollution: A review. Environmental Pollution 173 245-254.

Harmens H, Norris, D.A, Cooper, D. M, Mills, G, Steinnes, E, Kubin, E, Thöni, L, Aboal, J. R, Alber, R,Carbella, A, Coskum M, de Temmerman, L, Frolova, M, González-Miqueo, L, Jeran, Z, Leblond, S, Liiv, S, Maňkovská, B, Pesch, Poikalainen, J, R, Rühling, Å, Santamaria, J.M, Simone, P, Schröder, W, Suchara, I, Yurukova, L, Zechmeister, H.G. (2011), Nitrogen concentrations in mosses indicate the spatial distribution of atmospheric nitrogen deposition in Europe, Environmental Pollution 159 2852-2860.

Harmens H, Norris D, Mills G. and the participants of the moss survey, (2013), Heavy metals and nitrogen in mosses: spatial patterns in 2010/2011 and long-term temporal trends in Europe, ICP Vegetation Programme Coordination Centre, Centre for Ecology and Hydrology, Bangor, UK, 63 p. http://icpvegetation.ceh.ac.uk

Harmens H, Norris DA, Steinnes E, Kubin E, Piispanen J, Alber R, Aleksiayenak Y, Blum O, Coşkun M, Dam M, De Temmerman L, Fernández JA, Frolova M, Frontasyeva M, González-Miqueo L, Grodzińska K, Jeran Z, Korzekwa S, Krmar M, Kvietkus K, Leblond S, Liiv S, Magnússon SH, Maňkovská B, Pesch R, Rühling Å, Santamaria JM, Schröder W, Spiric Z, Suchara I, Thöni L, Urumov V, Yurukova L, Zechmeister HG (2010) Mosses as biomonitors of atmospheric heavy metal deposition: spatial and temporal trends in Europe. Environmental Pollution 158, 31443156.

Howe P, Malcolm H, Dobson S (2004) Manganese and Its Compounds: Environmental Aspects. World Health Organization, Geneva, 63 p.

Huang X, Olmez I, Aras NK, Gordan GE (1994) Emmisions of trace elements from motor vehicles: potential marker elements and source composition profile. Atmospheric Environment 28 (8) 1385-1391.

IAEA-TECDOC-1338 (2003) Biomonitoring of atmospheric pollution (with emphasis on trace elements) — BioMAP II, Nutritional and Health-Related Environmental Studies Section International Atomic Energy Agency, Wagramer Strasse 5, P.O. Box 100, A-1400 Vienna, Austria, ISBN 92-0-100803-1, ISSN 1011-4289, ISBN 92-0-100803-1, (c) IAEA

ICP Vegetation (2010) Heavy Metals in European Mosses: Survey. Monitoring Manual. International Cooperative Programme on Effects of Air Pollution on Natural Vegetation and Crops, http://icpvegetation.ceh.ac.uk/manuals/documents/UNECEHEAVYMETALSMOSSMANUAL2010POPsadaptedfi nal_220510_.pdf

Lazo P, Cullaj A, Arapi A, Deda T (2007) Chapter 8, Arsenic in soil environments in Albania, pp.237-267 (included in the book: Arsenic in Soils and Groundwater Environment, Battacharia P, Mukherjee AB, Bundschuh J, Zevenhoven R,

Loeppert RH, Elsevier B.V.; Trace Metals and other Contaminants in the Environment, Vol. 9 237-256, Series editor: J.O. Nriagu (ISSN 0927-5215/ doi 30.1016/S0927-5215(06)090008-4))

Lazo P, Bekteshi L, Shehu A (2013) Active moss biomonitoring technique for atmospheric deposition of heavy metals study in Elbasan city, Albania, Fresenius Environmental Bulletin, PSP Volume 23 - No 1a 213-219 
Marinova S, Yurukova L, Frontasyeva VM, Steinnes E, Strelkova LP, Marinov A, Karadzhinova AG (2010) Air pollution studies in Bulgaria using the moss biomonitoring technique. Ecological Chemistry and Engineering, 17, 37-52.

Marka J, Sabovljevic M, 2011, New bryophyte records from Albania, Journal of Biology, Vol. 33 No. 1, 74-76

Markert B, Wappelhorst O, Weckert V, Herpin U, Siewers U, Friese K, Breulmann G (1999) The use of bioindicators for monitoring the heavy-metal status of the environment. Journal of Radioanalytical and Nuclear Chemistry. 240, (2), 425-429.

Markert B, Breure AM, Zechmeister HG (2003) Definitions, strategies and principles for bioindication/biomonitoring of the environment. In: Markert BA, Breure AM \& Zechmeister HG (eds) Bioindicators and biomonitors. Elsevier, Oxford, p 3-39.

Melaku S, Morris V, Raghavan D, Hosten C (2008) Seasonal variation of heavy metals in ambient air and precipitation at a single site in Washington, DC, Environmental Pollution 155, 88-98

Onianwa PC (2001) Monitoring Atmospheric Metal Pollution: A Review of the Use of Mosses as Indicators, Environmental Monitoring and Assessment , 71: 13-50.

Rudnick RL (2003) Composition of the Continental Crust, Treatise on Geochemistry, ISBN (set): 0-08-043751-6, Volume 3; pp. 1-64, http://www.geol.umd.edu/ rudnick/Webpage/Rudnick_Gao_Treatise.pdf

Schilling J, Lehman M. (2002) Bioindication of atmospheric heavy metal deposition in the Southeastern US using the moss thuidium delicatulum, Atmospheric Environment, 36 1611-1618

Stafilov T. Bojkovska R, Hirao M (2003) Air pollution monitoring system in the Republic of Macedonia. Journal of Environmental Protection and Ecology, 4, 518-524.

Steinnes E, Berg T, Uggerud H, Vadset M (2007) Atmospheric Deposition of Heavy Metals in Norway. Nation-wide survey in 2005. State Program for Pollution Monitoring, Report 980/2007, Norwegian State Pollution Control Authority, Oslo 2007, 36 pp. (In Norwegian)

Steinnes E, Rühling Å, Lippo H, Makinen A (1997) Reference materials for large-scale metal deposition surveys. Accreditation and Quality Assurance 2 243-249.

Steinnes E (1995) A critical evaluation of the use of naturally growing moss to monitor the deposition of atmosferic metals, The Science of the Total Environment 160/161 243-249.

Steinnes E, Berg T, Uggerud TH, Pfaffhuber KA (2011) Atmospheric deposition of heavy metals in Norway, National Study in 2010, Rapport 1109/2011, Norwegian University of Science and Technology(NTNU), Trondheim (in Norwegian); http://www.miljodirektoratet.no/old/klif/publikasjoner/2859/ta2859.pdf

Spiric Z, Frontasyeva VM, Stafilov T (2012) Multi-element atmospheric deposition study in Croatia. International Journal of Environmental Analytical Chemistry, Taylor\&Francis, Vol. 92, No. 10, p. 1200-1214, http://dx.doi.org/10.1080/03067319.2011.561336

Thöni L, Yurukova, L, Bergamini, A, Ilyin, I, Matthaei, D (2011) Temporal trends and spatial patterns of heavy metal concentrations in mosses in Bulgaria and Switzerland: 1990-2005, Atmospheric Environment, 45 1899-1912.

Tume P, Bech J, Reverter F, Bech J, Longan L, Tume L, Sepúlveda B (2010) Concentration and distribution of twelve metals in Central Catalonia surface soils, Journal of Geochemical Exploration, GEXPLO-04846; No of Pages 12, http://www.portal.ufra.edu.br/attachments/641 Lorena\%20metais\%20na\%20Catalunia.pdf

Vaughan IP, Ormerod SJ (2005) Increasing the value of principal components analysis for simplifying ecological data: a case study with rivers and river birds, Journal of Applied Ecology, 42, 4872005.

Vujičić M, Sabovljević A, Sabovljević M, 2010, Axenically culturing the bryophytes: establishment and propagation of the moss Hypnum cupressiforme Hedw.(Bryophyta, Hypnaceae) in in vitro conditions, Botanica Serbica, vol. 35 (1), 71-77

Wang Z, Darilek JL, Zhao Y, Huang B, Sun W (2010) Defining soil geochemical baselines at small scales using geochemical common factors and soil organic matter as normalizers, Journal of Soils and Sediments, Pages 12, DOI 10.1007/s11368-010-0269-4

Wehner B, Wiedensohler A (2002) Long term measurements of submicrometer urban aerosols: statistical analysis for correlations with meteorological conditions and trace gases, Atmospheric Chemistry and Physics 2 1699-1733, www.atmos-chem-phys.org/acpd/2/1699/

WBK \& Associates Inc (2004), Assessment Report On Manganese For Developing Ambient Air Quality Objectives, ISBN No 0-7785-3949-0 (On-Line Edition), http://Www3.Gov.Ab.Ca/Env/Info/Infocentre/Publist.Cfm

Zeichmeister HG, Hohenwallner D, Riss A, Hanus-Illnar A (2003) Variation in Heavy Metal Concentrations in the Moss Species Abietinella Abietina (Hedw.) Fleisch According to Sampling Time, Within Site Variability and Increase in Biomass, Science of the Total Environment, 301: 55-65. 


\begin{tabular}{|c|c|c|c|c|c|}
\hline Station & Latitude & Longitude & Station & Latitude & \begin{tabular}{|l|} 
Longitule \\
\end{tabular} \\
\hline Stl & 200943 & 393956 & St.32 & 201430 & 412940 \\
\hline St.2 & 200045 & 395243 & St.33 & 200128 & 413617 \\
\hline St.3 & 201051 & 395455 & St.34 & 202406 & 415925 \\
\hline St.A & 200610 & 395651 & St.35 & $2023 \leqslant 3$ & 115856 \\
\hline St.5 & 201610 & 305557 & St.36 & 193125 & 402634 \\
\hline St 6 & 202138 & 395429 & St.37 & 193354 & 401512 \\
\hline St.7 & 201608 & 400150 & St.38 & 193507 & 401231 \\
\hline St.8 & 200560 & 400925 & St.39 & 193832 & 401520 \\
\hline St.9 & 201023 & 400156 & St.40 & 193513 & 402443 \\
\hline St.10 & 200206 & 401540 & St.41 & 193604 & 404043 \\
\hline St.11 & 200037 & 101530 & St.12 & 103830 & 101855 \\
\hline St.12 & 200102 & 401739 & St.43 & 193022 & $40 \quad 4119$ \\
\hline St.13 & 195836 & 402117 & St.44 & 194249 & 40.5556 \\
\hline St.14 & 200711 & 401740 & St.45 & 195502 & 404814 \\
\hline St.15 & 201830 & 401504 & St.46 & 194649 & 411230 \\
\hline St.16 & 201309 & 39.5911 & St.47 & 193143 & 411442 \\
\hline St.17 & 202042 & 401351 & St.48 & 194108 & 412247 \\
\hline St.18 & 202528 & 401247 & St.49 & 193733 & 412291 \\
\hline St.19 & 203249 & 400624 & St.50 & 194842 & 411859 \\
\hline St.20 & 204942 & 403952 & St.51 & 195228 & 412110 \\
\hline St.21 & 204138 & 402423 & St.52 & 194324 & 411786 \\
\hline St.22 & $\begin{array}{lll}20 & 0114\end{array}$ & 403621 & St 53 & 103085 & 411571 \\
\hline St.23 & 205545 & 405055 & St.54 & 193505 & 412925 \\
\hline St.24 & 203758 & 410357 & St.55 & 193653 & 412555 \\
\hline St.25 & 204252 & 405046 & St.56 & 195337 & 414546 \\
\hline St.26 & 201048 & 405319 & St.57 & 194350 & 414140 \\
\hline St.27 & 200435 & 405811 & St.58 & 193946 & 414725 \\
\hline St.28 & 204252 & 405040 & St.5y & 195639 & 413101 \\
\hline St.29 & 200243 & 110810 & St.60 & 102324 & 420427 \\
\hline St.30 & 200243 & 410810 & St.61 & 193126 & 422419 \\
\hline St.31 & 200421 & 410411 & St62 & 202353 & 422952 \\
\hline
\end{tabular}

Fig. 1 Map of Albania with moss sampling sites and their coordinates
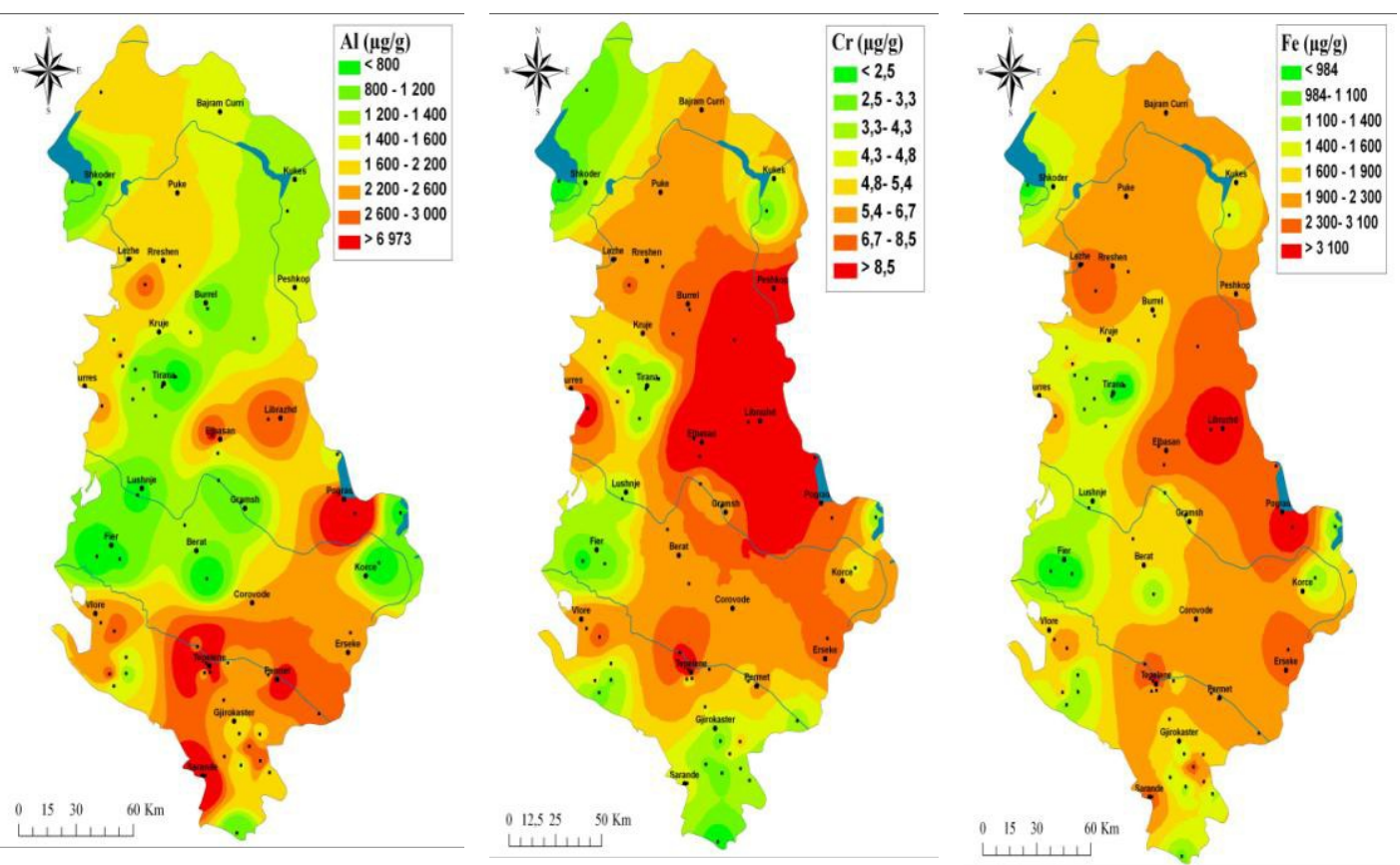

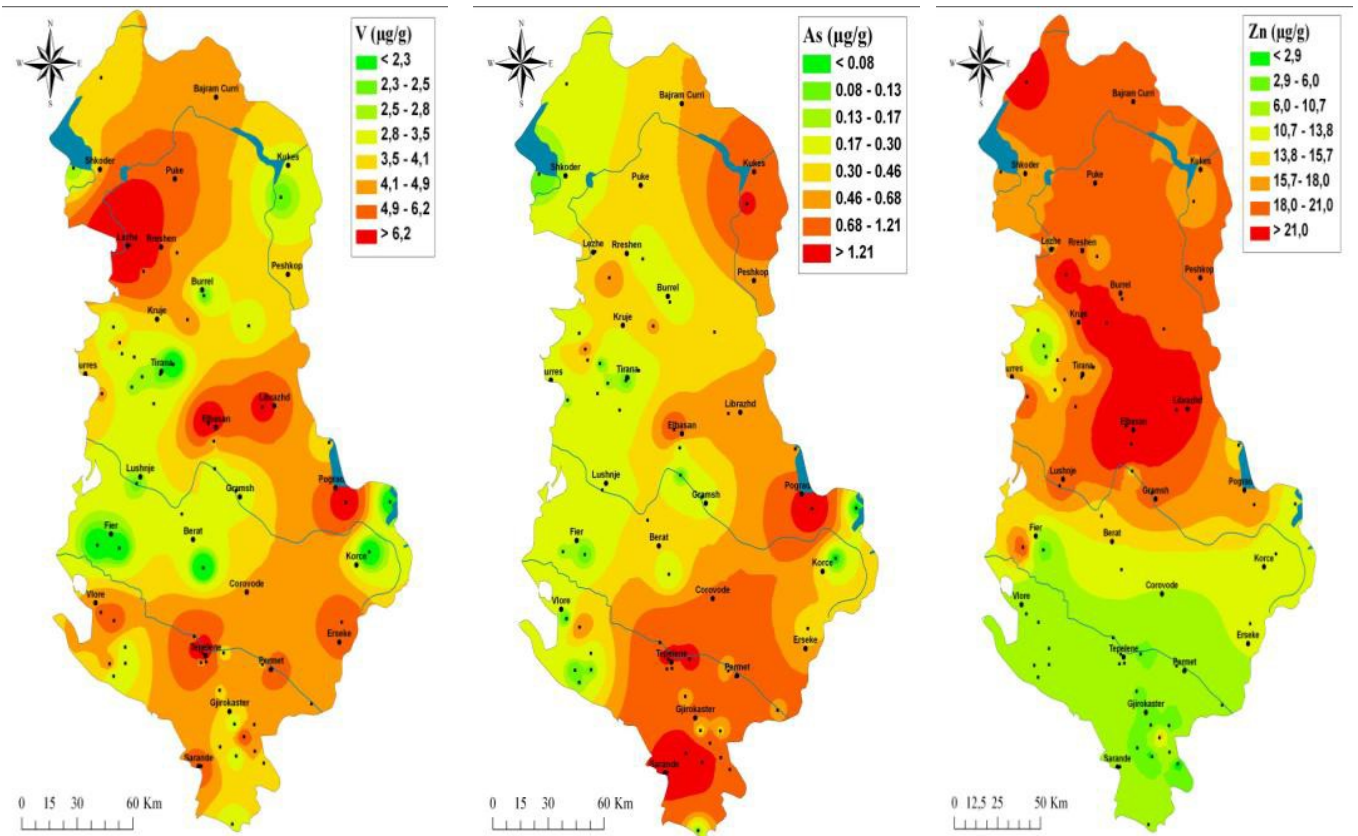

Fig. 2 The map of elements distribution (Al, Cr, Fe, V and As; C5, C4 and C3 contamination scale, and Zn; C1 contamination scale)

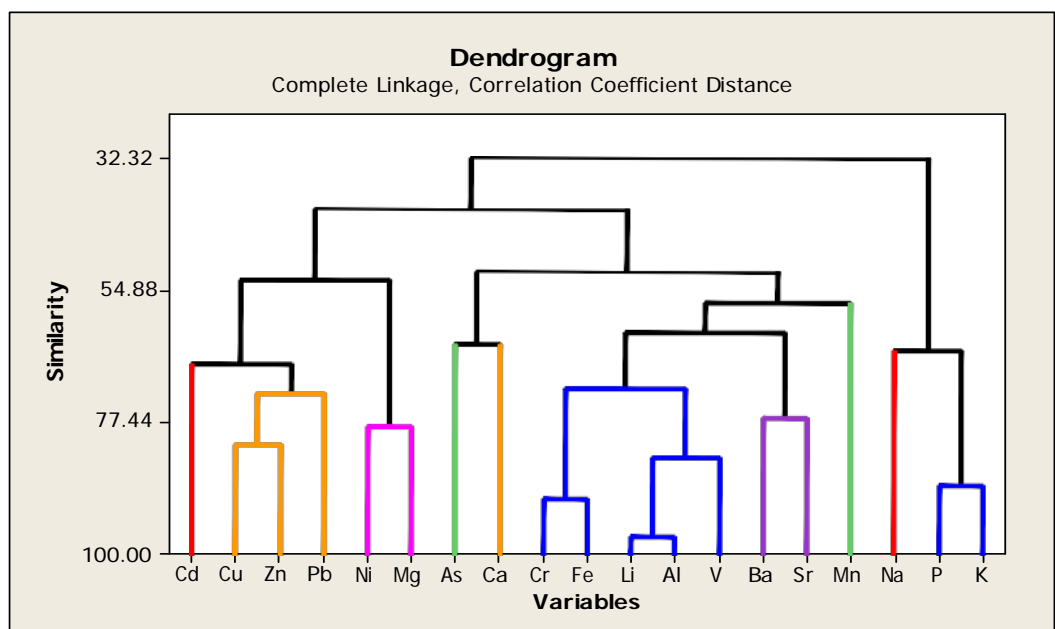

Fig. 3 Dendrogram of correlation coefficients for distance of clusters (Similarity level = 80\%) of deposited elements to mosses in Albania. Final Partition: Cluster 1: Cd; Cluster 2: As; Cluster 3: Cr, Li, V, Al and Fe; Cluster 4: $\mathrm{Cu}, \mathrm{Pb}$ and Zn; Cluster 5: Ni and Mg; Cluster 6: Ba and Sr; Cluster 7: Na: Cluster 8: Mn; Cluster 9: P and K; Cluster 10: Ca 
Table 1. Recommended (Steinnes et al., 1997; Harmens et al., 2010) and obtained values for element

concentration in reference moss samples M2 and M3.

\begin{tabular}{|c|c|c|c|c|}
\hline Element & \multicolumn{2}{|c|}{ M2 } & \multicolumn{2}{c|}{ M3 } \\
\hline & $\begin{array}{c}\text { Certified value } \pm \text { SD, } \\
\mathrm{mg} \mathrm{kg}^{-1}\end{array}$ & $\begin{array}{c}\text { Obtained value } \pm \text { SD, } \\
\mathrm{mg} \mathrm{kg}^{-1}\end{array}$ & $\begin{array}{c}\text { Certified value } \pm \text { SD, } \\
\mathrm{mg} \mathrm{kg}^{-1}\end{array}$ & $\begin{array}{c}\text { Obtained value } \pm \text { SD, } \\
\mathrm{mg} \mathrm{kg}^{-1}\end{array}$ \\
\hline $\mathrm{Al}$ & $178 \pm 15$ & $180 \pm 7$ & $169 \pm 10$ & $0.10 \pm \pm 0.01$ \\
\hline $\mathrm{As}$ & $17.6 \pm 0.7$ & $1.27 \pm 0.07$ & $105 \pm 0.007$ & $12.1 \pm 0.7$ \\
\hline $\mathrm{Ba}$ & $2050 \pm 160$ & $16.15 \pm 0.7$ & $2140 \pm 200$ & $1816 \pm 139$ \\
\hline $\mathrm{Ca}$ & $0.454 \pm 0.019$ & $0.42 \pm 0.04$ & $0.106 \pm 0.05$ & $0.09 \pm 0.03$ \\
\hline $\mathrm{Cd}$ & $0.97 \pm 0.17$ & $0.92 \pm 0.05$ & $0.67 \pm 0.19$ & $0.59 \pm 0.02$ \\
\hline $\mathrm{Cr}$ & $68.7 \pm 2.5$ & $69.2 \pm 9.9$ & $3.76 \pm 0.23$ & $5.3 \pm 0.35$ \\
\hline $\mathrm{Cu}$ & $262 \pm 35$ & $259 \pm 9$ & $138 \pm 12$ & $156 \pm 5$ \\
\hline $\mathrm{Fe}$ & $6980 \pm 350$ & $6470 \pm 103$ & $3510 \pm 280$ & $4235 \pm 165$ \\
\hline $\mathrm{K}$ & $826 \pm 52$ & $774 \pm 33$ & $755 \pm 77$ & $731 \pm 96$ \\
\hline $\mathrm{Mg}$ & $342 \pm 17$ & $305 \pm 33$ & $535 \pm 30$ & $466 \pm 8$ \\
\hline $\mathrm{Mn}$ & $166 \pm 15$ & $165 \pm 27$ & $133 \pm 12$ & $120 \pm 6$ \\
\hline $\mathrm{Na}$ & $16.3 \pm 0.9$ & $16.3 \pm 1.41$ & $0.95 \pm 0.08$ & $1.0 \pm .0 .20$ \\
\hline $\mathrm{Ni}$ & $6.37 \pm 0.43$ & $6.1 \pm 0.9$ & $3.33 \pm 0.25$ & $3.40 \pm 0.05$ \\
\hline $\mathrm{Pb}$ & $5.31 \pm 0.15$ & $5.01 \pm 0.26$ & $4.64 \pm 0.24$ & $4.69 \pm 0.27$ \\
\hline $\mathrm{Sr}$ & $1.43 \pm 0.17$ & $1.45 \pm 0.37$ & $1.19 \pm 0.15$ & $1.26 \pm 0.33$ \\
\hline $\mathrm{V}$ & $36.1 \pm 1.2$ & $34.3 \pm 2.83$ & $25.4 \pm 1.1$ & $23.7 \pm 1.2$ \\
\hline $\mathrm{Zn}$ & & & & \\
\hline
\end{tabular}

Table 2 Descriptive statistics of mosses elements in Albania $(\mathrm{N}=62)(\mathrm{mg} / \mathrm{kg}, \mathrm{DW})$

\begin{tabular}{ccccccccc} 
Element & Minimum & Mean & Median & Maximum & ST.DEV & CV $(\%)$ & Kurtosis & Skewness \\
\hline $\mathrm{As}$ & 0.05 & 0.541 & 0.305 & 2.86 & 0.64 & 118 & 3.51 & 1.97 \\
$\mathrm{Cd}$ & 0.04 & 0.170 & 0.107 & 0.9 & 0.16 & 97 & 8.57 & 2.81 \\
$\mathrm{Li}$ & 0.28 & 1.644 & 1.425 & 5.58 & 1.01 & 61 & 4.01 & 1.78 \\
$\mathrm{Sr}$ & 10.8 & 22.19 & 21.7 & 47.2 & 6.27 & 28 & 3.52 & 1.24 \\
$\mathrm{~V}$ & 1.15 & 4.23 & 3.51 & 16.9 & 2.79 & 66 & 7.50 & 2.40 \\
$\mathrm{Zn}$ & 1.00 & 14.06 & 13.8 & 68.1 & 11.6 & 82 & 8.10 & 2.26 \\
$\mathrm{Ba}$ & 6.00 & 21.87 & 21.21 & 42.8 & 8.34 & 38 & -0.40 & 0.21 \\
$\mathrm{Ni}$ & 1.56 & 11.36 & 5.85 & 131 & 19.3 & 170 & 27.1 & 4.83 \\
$\mathrm{~Pb}$ & 1.34 & 3.28 & 2.41 & 19.7 & 3.21 & 98 & 17.3 & 4.05 \\
$\mathrm{Cr}$ & 1.62 & 6.38 & 4.75 & 31.8 & 5.39 & 85 & 9.65 & 2.84 \\
$\mathrm{Cu}$ & 2.14 & 6.07 & 5.58 & 15.7 & 2.80 & 46 & 3.13 & 1.49 \\
$\mathrm{Mn}$ & 22.12 & 70.45 & 56.3 & 284 & 50.72 & 72 & 6.57 & 2.40 \\
$\mathrm{Na}$ & 27.9 & 94.54 & 87.1 & 338 & 50.79 & 54 & 8.89 & 2.39 \\
$\mathrm{Al}$ & 535 & 1958 & 1638 & 6974 & 1178 & 60 & 4.89 & 1.76 \\
$\mathrm{Ca}$ & 4424 & 7094 & 6734 & 12433 & 1715 & 24 & 0.38 & 0.84 \\
$\mathrm{Fe}$ & 469 & 1892 & 1618 & 5488 & 1105 & 58 & 2.66 & 1.64 \\
$\mathrm{~K}$ & 1831 & 3736 & 3414 & 10043 & 1706 & 46 & 2.94 & 1.62 \\
$\mathrm{Mg}$ & 1140 & 2576 & 2347 & 5152 & 1033 & 40 & -0.58 & 0.54 \\
$\mathrm{P}$ & 407 & 792 & 756 & 1839 & 286 & 36 & 3.09 & 1.53 \\
\hline
\end{tabular}

Table 3 The comparison of median values from Albania and a a pristine region of Northern Norway (Steinnes 2007)

\begin{tabular}{|c|c|c|c|c|}
\hline & \multicolumn{2}{|c|}{ Albania, 2010 } & \multicolumn{2}{c|}{$\begin{array}{c}\text { Norway, 2005 (Steinnes } \\
\text { et al., 2007) }\end{array}$} \\
\hline Element & Median & Range & Median & Range \\
\hline $\mathrm{Al}$ & 1650 & $535-6974$ & 200 & $67-820$ \\
\hline $\mathrm{As}$ & 0.31 & $0.05-2.86$ & 0.093 & $0.020-0.505$ \\
\hline $\mathrm{Ba}$ & 21.3 & $6.0-42.8$ & 17.1 & $5.6-50.5$ \\
\hline $\mathrm{Ca}$ & 6850 & $4420-12433$ & 2820 & $1680-5490$ \\
\hline
\end{tabular}




\begin{tabular}{|c|c|c|c|c|}
\hline $\mathrm{Cd}$ & 0.109 & $0.038-0.90$ & 0.058 & $0.025-0.171$ \\
\hline $\mathrm{Cu}$ & 5.58 & $2.14-15.66$ & 3.6 & $2.1-9.2$ \\
\hline $\mathrm{Cr}$ & 4.83 & $1.60-31.76$ & 0.55 & $0.10-4.2$ \\
\hline $\mathrm{Fe}$ & 1609 & $469-5488$ & 209 & $77-1370$ \\
\hline $\mathrm{Mg}$ & 2451 & $1140-5152$ & 1730 & $940-2370$ \\
\hline $\mathrm{Mn}$ & 56 & $22-284$ & 256 & $22-750$ \\
\hline $\mathrm{Ni}$ & 5.8 & $1.6-131$ & 1.14 & $0.12-6.6$ \\
\hline $\mathrm{Pb}$ & 2.42 & $1.34-19.74$ & 1.17 & $0.64-6.12$ \\
\hline $\mathrm{Sr}$ & 21.6 & $0.8-47.2$ & 15.8 & $3.6-43.3$ \\
\hline $\mathrm{V}$ & 3.52 & $1.15-16.95$ & 0.92 & $0.39-5.1$ \\
\hline $\mathrm{Zn}$ & 13.8 & $1.0-68.1$ & 26.5 & $7.9-173$ \\
\hline
\end{tabular}

Table 4 The data of the contamination factors (CF) and Contamination Classification (Fernandez et al. 2000) for metal concentrations in mosses in Albania.

\begin{tabular}{|c|c|c|c|c|c|c|c|c|c|c|c|c|c|c|c|}
\hline Parameter & $\mathrm{Al}$ & As & $\mathrm{Ba}$ & $\mathrm{Ca}$ & $\mathrm{Cd}$ & $\mathrm{Cr}$ & $\mathrm{Cu}$ & $\mathrm{Fe}$ & $\mathrm{Mg}$ & Mn & $\mathrm{Ni}$ & $\mathrm{Pb}$ & $\mathrm{Sr}$ & $\mathrm{V}$ & $\mathrm{Zn}$ \\
\hline $\mathrm{CF}$ & 8.25 & 3.33 & 1.25 & 2.43 & 1.88 & 8.78 & 1.55 & 7.80 & 1.42 & 0.22 & 5.10 & 2.07 & 1.36 & 3.83 & 0.52 \\
\hline Classification & C5 & C3 & $\mathrm{C} 2$ & C3 & $\mathrm{C} 2$ & C5 & C2 & $\mathrm{C} 4$ & $\mathrm{C} 2$ & $\mathrm{C} 1$ & C4 & C3 & $\mathrm{C} 2$ & $\mathrm{C} 4$ & $\mathrm{C} 1$ \\
\hline Contamination & 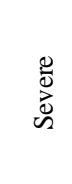 & $\begin{array}{l}\overrightarrow{\vec{c}} \\
\frac{.00}{\omega}\end{array}$ & 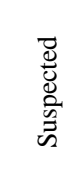 & $\begin{array}{l}\overrightarrow{\vec{*}} \\
\stackrel{.00}{\bar{\omega}}\end{array}$ & 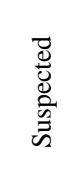 & 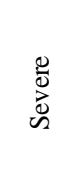 & 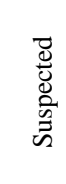 & $\begin{array}{l}\frac{\pi}{\pi} \\
\frac{\pi}{0} \\
\dot{0}\end{array}$ & 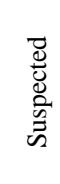 & 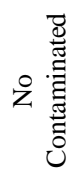 & $\begin{array}{l}\frac{\pi}{\pi} \\
\frac{\pi}{0} \\
\frac{0}{2}\end{array}$ & 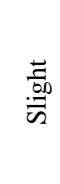 & 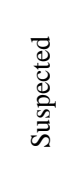 & $\begin{array}{l}\frac{\pi}{\pi} \\
\frac{\pi}{0} \\
\frac{0}{\Sigma}\end{array}$ & 之藅 \\
\hline
\end{tabular}

Table 5 Pearson Correlation Coefficient between element concentrations in mosses in Albania.

\begin{tabular}{|c|c|c|c|c|c|c|c|c|c|c|c|c|c|}
\hline & $\mathrm{Cd}$ & As & $\mathrm{Cr}$ & $\mathrm{Cu}$ & $\mathrm{Li}$ & $\mathrm{Pb}$ & $\mathrm{Ni}$ & V & $\mathrm{Zn}$ & $\mathrm{Ba}$ & $\mathrm{Sr}$ & $\mathrm{Na}$ & $\mathrm{Mn}$ \\
\hline As & 0.19 & & & & & & & & & & & & \\
\hline $\mathrm{Cr}$ & $0.46^{1}$ & 0.18 & & & & & & & & & & & \\
\hline $\mathrm{Cu}$ & $0.39^{2}$ & -0.05 & 0.31 & & & & & & & & & & \\
\hline $\mathrm{Li}$ & $0.37^{2}$ & $0.60^{1}$ & $0.45^{1}$ & 0.27 & & & & & & & & & \\
\hline $\mathrm{Pb}$ & $0.35^{3}$ & 0.08 & 0.26 & $0.45^{1}$ & 0.23 & & & & & & & & \\
\hline $\mathrm{Ni}$ & 0.21 & -0.01 & $0.64^{1}$ & 0.14 & 0.09 & 0.06 & & & & & & & \\
\hline $\mathrm{V}$ & 0.30 & $0.34^{3}$ & $0.51^{1}$ & 0.30 & $0.75^{1}$ & 0.31 & 0.13 & & & & & & \\
\hline $\mathrm{Zn}$ & $0.43^{1}$ & -0.09 & 0.43 & $0.62^{1}$ & 0.19 & $0.52^{1}$ & 0.21 & $0.34^{3}$ & & & & & \\
\hline $\mathrm{Ba}$ & 0.21 & 0.29 & 0.24 & 0.05 & $0.56^{1}$ & -0.04 & 0.06 & $0.42^{2}$ & -0.01 & & & & \\
\hline $\mathrm{Sr}$ & 0.21 & 0.24 & 0.43 & 0.06 & $0.50^{1}$ & 0.22 & 0.12 & $0.60^{1}$ & 0.34 & $0.54^{1}$ & & & \\
\hline $\mathrm{Na}$ & 0.01 & -0.35 & -0.13 & 0.21 & -0.27 & -0.03 & -0.09 & -0.19 & 0.19 & -0.21 & -0.26 & & \\
\hline $\mathrm{Mn}$ & $0.35^{3}$ & 0.27 & 0.24 & $0.40^{2}$ & $0.57^{1}$ & 0.04 & 0.09 & $0.37^{2}$ & 0.14 & $0.39^{2}$ & 0.14 & -0.07 & \\
\hline $\mathrm{Al}$ & $0.34^{3}$ & $0.60^{1}$ & $0.43^{1}$ & 0.11 & $0.94^{1}$ & 0.12 & 0.08 & $0.67^{1}$ & 0.02 & $0.65^{1}$ & $0.51^{1}$ & -0.3 & $0.56^{1}$ \\
\hline $\mathrm{Fe}$ & $0.43^{2}$ & $0.44^{1}$ & $0.81^{1}$ & $0.38^{2}$ & $0.81^{1}$ & 0.30 & $0.51^{1}$ & $0.72^{1}$ & 0.39 & $0.46^{1}$ & $0.52^{1}$ & -0.21 & $0.49^{1}$ \\
\hline $\mathrm{P}$ & -0.04 & -0.15 & -0.26 & 0.15 & -0.21 & 0.01 & -0.24 & -0.26 & 0.01 & 0.02 & -0.33 & 0.31 & 0.15 \\
\hline $\mathrm{K}$ & -0.13 & -0.23 & -0.21 & 0.02 & -0.22 & -0.16 & -0.25 & -0.25 & -0.03 & 0.13 & -0.18 & 0.48 & -0.03 \\
\hline $\mathrm{Mg}$ & 0.18 & -0.14 & $0.50^{1}$ & $0.48^{1}$ & 0.02 & 0.25 & $0.56^{1}$ & 0.14 & $0.60^{1}$ & -0.17 & -0.02 & 0.2 & 0.08 \\
\hline $\mathrm{Ca}$ & 0.20 & 0.28 & 0.26 & 0.05 & 0.43 & 0.31 & -0.87 & $0.35^{3}$ & 0.17 & 0.13 & 0.16 & -0.28 & 0.03 \\
\hline
\end{tabular}

\begin{tabular}{|c|c|c|c|c|c|}
\hline & $\mathrm{Al}$ & $\mathrm{Fe}$ & $\mathrm{P}$ & $\mathrm{K}$ & $\mathrm{Mg}$ \\
\hline $\mathrm{Fe}$ & $0.75^{1}$ & & & & \\
\hline $\mathrm{P}$ & -0.17 & -0.3 & & & \\
\hline K & -0.13 & -0.31 & $0.76^{1}$ & & \\
\hline $\mathrm{Mg}$ & -0.18 & 0.43 & -0.15 & -0.29 & \\
\hline $\mathrm{Ca}$ & $0.42^{1}$ & 0.26 & -0.04 & -0.13 & -0.08 \\
\hline
\end{tabular}

Cell Contents: P-Value: ${ }^{1} \mathrm{P}<0.001,{ }^{2} \mathrm{P}<0.005,{ }^{3} \mathrm{P}<0.01$ 
Table 6 Statistical parameters of linear regressions between significantly correlated elements in mosses in

Albania (tcrit(0.05, N-2=60=2).
\begin{tabular}{|l|c|c|c|l|c|c|c|}
\hline \multicolumn{1}{|c|}{ Linear Equation } & $\mathrm{R}^{2}$ & $\mathrm{~S}$ & $\mathrm{t}$ & Linear Equation & $\mathrm{R}^{2}$ & $\mathrm{~S}$ & $\mathrm{t}$ \\
\hline $\mathrm{Li}=0.0466+0.000822 \mathrm{Al}$ & 0.89 & 0.334 & 7.3 & $\mathrm{Fe}=677.8+288.5 \mathrm{~V}$ & 0.53 & 759 & 5.5 \\
\hline $\mathrm{Li}=0.2311+0.000753 \mathrm{Fe}$ & 0.67 & 0.587 & 6.3 & $\mathrm{Fe}=1133+10.87 \mathrm{Mn}$ & 0.25 & 956 & 3.8 \\
\hline $\mathrm{Li}=0.4831+0.2791 \mathrm{~V}$ & 0.57 & 0.662 & 5.8 & $\mathrm{Fe}=1445+804.9 \mathrm{As}$ & 0.22 & 975 & 3.6 \\
\hline $\mathrm{Li}=1.098+1.009 \mathrm{As}$ & 0.40 & 0.789 & 4.9 & $\mathrm{Al}=1302+1185 \mathrm{As}$ & 0.42 & 893 & 4.9 \\
\hline $\mathrm{Li}=0.8486+0.0116 \mathrm{Mn}$ & 0.32 & 0.833 & 4.4 & $\mathrm{Al}=763.8+283.7 \mathrm{~V}$ & 0.45 & 864 & 5.1 \\
\hline $\mathrm{Li}=1.106+0.08799 \mathrm{Cr}$ & 0.21 & 0.902 & 3.5 & $\mathrm{Al}=1041+13.15 \mathrm{Mn}$ & 0.32 & 963 & 4.3 \\
\hline $\mathrm{Fe}=504.5+0.7078 \mathrm{Al}$ & 0.56 & 727.63 & 5.8 & $\mathrm{Al}=1360+95.50 \mathrm{Cr}$ & 0.19 & 1051 & 3.3 \\
\hline $\mathrm{Fe}=838.3+169.0 \mathrm{Cr}$ & 0.66 & 638.29 & 6.3 & $\mathrm{~K}=114.1+4.508 \mathrm{P}$ & 0.58 & 1087 & 5.9 \\
\hline
\end{tabular}

Table 7 Factor Loadings (Varimax Rotation) of moss elements in the studied area

\begin{tabular}{|c|c|c|c|c|c|c|}
\hline Variable & Factor 1 & Factor 2 & Factor 3 & Factor 4 & Factor 5 & Communality \\
\hline $\mathrm{Al}$ & $\mathbf{0 . 8 5 8}$ & -0.076 & -0.042 & 0.213 & 0.377 & 0.931 \\
\hline $\mathrm{As}$ & $\mathbf{0 . 5 2 6}$ & -0.175 & 0.013 & 0.432 & 0.323 & 0.598 \\
\hline $\mathrm{Ba}$ & $\mathbf{0 . 8 0 8}$ & -0.023 & 0.152 & -0.148 & 0.112 & 0.711 \\
\hline $\mathrm{Ca}$ & 0.304 & -0.320 & $\mathbf{- 0 . 5 2 9}$ & 0.286 & 0.009 & 0.556 \\
\hline $\mathrm{Cd}$ & 0.274 & 0.249 & $\mathbf{- 0 . 4 6 1}$ & 0.008 & 0.303 & 0.442 \\
\hline $\mathrm{Cr}$ & $\mathbf{0 . 4 9 1}$ & $\mathbf{0 . 6 6 9}$ & -0.241 & 0.113 & 0.042 & 0.761 \\
\hline $\mathrm{Cu}$ & -0.018 & 0.297 & $\mathbf{- 0 . 6 7 0}$ & -0.238 & $\mathbf{0 . 4 3 2}$ & 0.781 \\
\hline $\mathrm{Fe}$ & $\mathbf{0 . 6 9 9}$ & $\mathbf{0 . 5 1 9}$ & -0.220 & 0.223 & 0.275 & 0.932 \\
\hline $\mathrm{K}$ & 0.048 & -0.272 & 0.119 & $\mathbf{- 0 . 8 8 1}$ & -0.028 & 0.867 \\
\hline $\mathrm{Li}$ & $\mathbf{0 . 8 0 0}$ & 0.030 & -0.201 & 0.249 & 0.400 & 0.903 \\
\hline $\mathrm{Mg}$ & -0.176 & $\mathbf{0 . 8 3 0}$ & $\mathbf{- 0 . 3 2 5}$ & 0.031 & 0.086 & 0.834 \\
\hline $\mathrm{Mn}$ & 0.391 & 0.126 & -0.018 & -0.092 & $\mathbf{0 . 7 8 6}$ & 0.795 \\
\hline $\mathrm{Na}$ & -0.239 & 0.188 & -0.055 & $\mathbf{- 0 . 6 8 8}$ & -0.030 & 0.570 \\
\hline $\mathrm{Ni}$ & 0.100 & $\mathbf{0 . 8 1 3}$ & 0.078 & 0.132 & 0.033 & 0.696 \\
\hline $\mathrm{P}$ & -0.140 & -0.324 & -0.107 & $\mathbf{- 0 . 7 5 4}$ & 0.232 & 0.759 \\
\hline $\mathrm{Pb}$ & 0.021 & -0.011 & $\mathbf{- 0 . 8 4 6}$ & 0.068 & -0.102 & 0.732 \\
\hline $\mathrm{Sr}$ & $\mathbf{0 . 7 8 5}$ & 0.148 & -0.171 & 0.098 & -0.354 & 0.803 \\
\hline $\mathrm{V}$ & $\mathbf{0 . 7 3 0}$ & 0.167 & -0.321 & 0.173 & 0.076 & 0.699 \\
\hline $\mathrm{Zn}$ & 0.120 & 0.456 & $\mathbf{- 0 . 7 2 2}$ & -0.196 & -0.42 & 0.783 \\
\hline $\mathrm{Variance}$ & 4.638 & 2.846 & 2.623 & 2.444 & 1.601 & 14.125 \\
\hline$\% \mathrm{Var}$ & 24.4 & 15.0 & 13.8 & 12.9 & 8.4 & 74.5 \\
\hline & & & & & & \\
\hline
\end{tabular}

